\title{
Ideology, Politics, and Opinion Journalism: A Content Analy- sis of Spanish Online-Only Newspapers
}

\author{
Antonio Pineda* and Núria Almiron** \\ *Universidad de Sevilla, Sevilla, España, apc@us.es \\ **Universidad Pompeu Fabra, Barcelona, España, nuria.almiron@upf.edu
}

\begin{abstract}
This study examines the ideological slant of Spanish digital-native opinion journalism. Political-ideological pluralism is a well-researched topic in media and journalism studies, yet there is less research regarding this topic when it comes to exclusively online media. This paper addresses that gap concerning the ways online-only opinion journalism can be defined in terms of their political ideology, and to what extent extreme ideological positions are represented in online journalism. Evidence from a content analysis of opinion columns appearing in the most widely-read Spanish online newspapers, during the month of May 2011 shows a general anti-left bias in the opinion sections of the newspapers, as well as a representation of the political extremes that is slightly more lenient with the extreme right. In line with Hallin and Mancini's theory of polarized political news environments in countries like Spain, our results show that this polarization is characterized by a strong-but not always explicit-dominance of right-wing views.
\end{abstract}

Keywords: Ideology, Politics, Content Analysis, Online-Only Media, Pluralism, Spain

Acknowledgement: Part of this research was funded by University of Seville.

By the standards set out in Hallin and Mancini's Comparing Media Systems (2004), Spain is one of the Mediterranean countries that is distinguished by a polarized pluralist media model. According to this model, the news media are "characterized by a high degree of external pluralism, in which media are seen as champions of diverse political ideologies, and commitment to these ideologies tends to outweigh commitment to a common professional culture" (2004, 298). Hallin and Mancini provide ample evidence of the high level of politicization in their model, and researchers of media pluralism and media ideology in Spain and other Mediterranean countries have recurrently studied this politicized scenario, providing different examples of the external pluralism mentioned above. External pluralism is a situation in which social and political diversity is not reflected across every media outlet. Under this scenario, every media outlet misses out on the representation of different cultural groups and divergent political or ideological opinions and viewpoints. Yet, diversity is supposed to be found within all outlets, due to the diversity of suppliers and/or media owners (Doyle 2002, 12). Either with internal or external pluralism, a common concern exists: to what extent is there balance amongst different viewpoints and, therefore, amongst different ideologies in a so-called pluralist media system?

The motivation for this study relates to the depiction and presence of political ideologies in the press. This motivation relies on the assumption that Spanish media are politically and ideologically biased, according to Hallin and Mancini's theory. One way to clarify this ideological bias may be to analyze the way the media, including the press, depict political ideologies.

Traditional printed newspapers-and their digital editions-coexist today with a new kind of media: digital-native newspapers and magazines; i.e., online-only news outlets that have appeared exclusively on the web since their inception. This paper explores whether Spanish online-only newspapers contribute to balanced pluralistic views when representing ideologi- 
cal trends and values, or whether they depict a dominant system of ideological beliefs. We consider this to be an enticing question for research, as the Internet has been regarded as a space that enhances and amplifies the opportunities for all belief systems and/or viewpoints to be publicized, hence challenging some tenets of the polarized pluralist media model. On the other hand-and although the digital versions of the traditional print-based dominant media maintain their leadership_Spanish digital media is a dynamic, diverse, and everchanging field, as news outlets with varied political stances are continually emerging and disappearing; a changing tableau which may enable the representation of a wide range of ideologies and political options. Some of these options may reach beyond the mainstream and take on extreme positions. Thus, this paper combines two areas of study: we examine the newer digital-native newspapers as well as the long-standing research topic of the relationship between the press and political ideologies.

\section{Ideology, Media, and the Digital Press}

Several meaningful and relevant lines of work have addressed the study of ideology and the media in general. Van Dijk is one of the most prolific authors to have investigated ideology and the media from the point of view of discourse analysis (see eg Van Dijk 1988, 2008). In "Opinions and Ideologies in the Press," the author uses editorial columns from The New York Times and The Washington Post to illustrate ideological analysis (1998). But where the issue has received the most attention is probably from the critical perspective of cultural studies and the political economy of communication. From the Birmingham School of Cultural Studies in Great Britain, the critical analysis of the concept of ideology is a central theme in which Hall introduces his post-Gramscian vision of hegemony-a term he uses to describe the process of the continuous social renewal of the cultural influence of one class over another. Hall $(1973,1982$ and 1996) frames the new cultural hegemony imposed by the mass media in the context of institutional, political, and economic power relations. Within the political economy of communication and culture, there is an even more extensive and prolific literature that considers the media as a tool for ideological manipulation: examples include the texts of Garnham (1986), Schiller (1973), Chomsky (1989 and 2002), Golding and Murdock (1996) and Chomsky and Herman (2002), which are now considered classics; or more recent contributions relevant to the Spanish state of affairs, Reig (2004), and Pineda (2009). Golding and Murdoch's affirmation that the primary raison d'être of the media is to sell, ideologicallyspeaking, the economic, political, and social system (i.e. the status quo) consolidates a tradition that has its roots in some of the most prominent Marxist authors in their writings about ideology (Althusser 1971, for example). Casasús's Ideología y análisis de medios de comunicación (Ideology and Media Analysis) contributes a combination of communication theory, structuralism, and semiotics anchored in Spanish society, where the author points to what he calls the "regressive theory." His understanding is that popular media are reactionary (Casasús 1985, 21).

Apart from these general theories about the content and ideological function of the media, there is an ample tradition of empirical study on the ideological role of the press. In this sense, we could cite the analysis on the reflection of French colonial policy and the justification of empire in the late nineteenth century in the weekly magazine Le Petit Journal Illustré (Rius Sanchis 2000); the ideological and political press during the Second Spanish Republic (1931-1936), which covered virtually the entire political spectrum, from the radical anarchist left to the extreme fascist right (Checa Godoy 2011); the role of Rupert Murdoch's The Australian as a pioneer of the libertarian right in the second half of the 1970s (McKnight 2003); the ideological role of newspapers like The New York Post (after its purchase by Murdoch in 1977) and The Washington Times in the service of the American right in the final decades of the twentieth century and the early twenty-first century (Brock 2005); or the business ideology in the Mexican newspaper El Norte de Monterrey (Smith Pussetto, García Pérez Vázquez and Esparza 2008). Researchers have also begun to apply ideological analysis of the press in countries normally outside of the focus of study, as in the case of Nigeria (Taiwo 2007, 243-244). 
In this context, it is striking that online-only journalism has been studied with much less intensity, even though the first digital-native newspapers emerged more than a decade and a half ago-in Spain, the first online-only newspapers Vilaweb and Hispanidad appeared in 1996. The most dominant and prolific tendency in studies related to online-only media focuses on the perspective of the strategies and characteristics of digital-native online media vs. non-native online media. However, there is some work that studies in more or less depth the varying ideological content of online-only journalism. In The Republican Noise Machine, Brock (2005, 159-163, 167-168), includes a critique of hard-right news sites like the successful WorldNetDaily, currently known as WND; and the work of Reig and Labio $(2006,1)$ focuses on the digital-native press from an ideological standpoint. The authors consider the three Spanish-language newspapers they analyze (Hispanidad, Rebelión, and Minuto Digital) to be extremist publications that enhance the prevailing partisanship of mainstream media. From another point of view, Steele's article (2009) about the online newspaper Malaysiakini (Malaysia Now) discusses how an independent news portal can pose a challenge to political authoritarianism. Nonetheless, the most direct reference to our study is Almiron's work (2006). The author performs a structural approach and presents a panorama of insufficiently plural viewpoints in the most widely-read digital news outlets. Even though the study provides data on editorial positions, the article does not analyze the messages of the headlines reviewed. To follow up on this study, we present the current paper.

Another factor that leads us to study the depiction of ideologies in online-only newspapers is the fact that some digital-native publications serve primarily as ideological or political outlets, as is the case of Spanish digital "confidential" journalism that tend to focus on topics rarely covered by the mainstream media, and which are consumed mostly along ideological lines (Sánchez González 2008, 162, 168). As well, Spanish "opinion cyber-newspapers" have been portrayed as a new genre characterized by a marked ideological slant (Varela 2005). On the other hand, some online publications arise as part of projects that follow clearcut political and ideological agendas, as in the case of the much visited American FrontPageMagazine.com, published by the Center for the Study of Popular Culture (renamed the David Horowitz Freedom Center in 2006), that was created with a deliberately anti-Left position and "to defend the principles of individual freedom, the rule of law, private property, and limited government" (Biography of David Horowitz). In Spain, the daily Hispanidad is described by its director and founder as "a Catholic newspaper" (Eulogio López, in Mújica). And the left-wing news and opinion site Rebelión tries, in its own words, to unveil "the interests hidden by capitalist economic and political powers in order to maintain their privileges and current status" (Nosotros).

Consequently, political-ideological positioning seems to be a relevant issue regarding online-only journalism. In this context, the aim of this paper is to bridge the supposed gap that exists between the political economy of communication and cultural studies. By providing content analysis data, we complement the existing political economy of communication research. The paper that is used as a direct reference for the current study (Almiron 2006) is an example of this kind of inquiry. The content analysis research of our study can be seen as a corroboration of the ideological bias identified by Almiron at the structural level. Our research focuses on one particular variety: opinion journalism. This genre is often guided by the political leanings of the newspaper, where the standard of objectivity is not applied and, therefore, the true ideology of the publication is revealed (Wahl-Jorgensen 2004). Given that the main objective of this study is to analyze the way ideological positions are depicted in contemporary Spanish online-only newspapers, the following research question can be formulated:

RQ1. How can opinion journalism in Spanish digital-only newspapers be defined regarding ideology?

It has been stated that the original purpose of opinion pages is to provide a vehicle for opinions that are divergent from those normally expressed in the news and editorial comments in the newspaper (Day and Golan 2005). This leads us to another research objective: 
to verify whether online-only journalism represents fringe ideologies. In this regard, it is remarkable that a subset of digital-native news outlets and sites position themselves not only as ideological publications, but as publications that veer from the political mainstream. The introduction of the Internet has affected the nature of political discourse (Gaskins and Jerit 2012:190). Some political consequences to take into account are the debate surrounding weblog journalism's ideological extremism (Allan 2009, 172-176), and the creation of hundreds of Websites by hate groups and extremist organizations (Sunstein 2001, 62-65). It must be taken into account the fact that the web provides a space for alternative media (Gillmor 2006, 144-148), and that the web facilitates radical communication (Curran 2005, 154). Certain Internet news outlets have been considered a subset of alternative media (Steele 2009:98), and digital media are often regarded as a way to enhance public discourse and encourage plurality. The British e-zine OpenDemocracy, for example, aims "to ensure that marginalized views and voices are heard" (cited in Curran and Witschge 2010, 108). Although there is evidence that information seeking online is related to reduced extremity (Wojcieszak and Rojas 2011, 501), radical media "have never been more accessible as they are today via the net" (Stanyer 2009, 212).

In Spain it is significant that the leading digital-native newspaper in the country by readership is Libertad Digital, a libertarian-conservative site that was launched in the year 2000 under the premise that unrestricted right-wing libertarian ideas were poorly represented in the Spanish media (Girauta 2007, 288). The aforementioned research by Almiron helps us to discern theoretically the extent of ideological extremism depicted in Spanish web-only journalism. Her research shows a homogeneous online media environment dominated by companies with a strong rightward-leaning conservative bias, "with radicalized ideologicalpolitical views that do not align with either the off-line audience's distribution or the moderation and political centrality of thought that surveys usually suggest regarding Spanish society" (Almiron 2006, 30). Given that there is a certain trend towards ideological extremism in online-only journalism (and in Spanish digital-native newspapers in particular) a second research question arises:

RQ2. To what extent are extreme ideological positions represented in the opinion content of Spanish online-only newspapers?

\section{Method}

Quantitative and qualitative content analysis (Holsti 1969; Berelson 1971; Krippendorff 2004) was used to study the characterization of ideologies in Spanish online-only newspapers. Content analysis has already been applied to study ideology and ideological strains (Lerner et al. 1951-1952, 715; Seider 1974). As shown above, the ideological analysis of newspapers and the media is a long-standing research topic; however, such an enticing topic is not easy to delimit from a conceptual point of view. Ideology is a widely debated concept (Tower Sargent 1996, 3), and it has been defined from a broad range of perspectives, from the classical Enlightenment notion of a "science of ideas," to the critical Marxist definition, to Postmodernism (Eagleton 1997). We describe the results of our content analysis in terms of political ideologies or dominant systems of belief (Van Dijk 2006). More specifically, ideologies are understood as sets of ideas that provide the basis for political action, and are related to power systems (Heywood 2007, 11). For example, "conservatism" and "socialism," as political ideologies, may be understood as different sets of beliefs that justify different ways of distributing political power.

In this sense, political ideologies can be categorized through the representation of the leftright ideological spectrum, ${ }^{1}$ as well as through the listing of the explicit presence of specific political ideologies. Anarchism, communism, socialism, social democracy, Christian democracy, liberalism (in the European, fiscally conservative sense), libertarianism/anarchocapitalism, conservatism, fascism, and nazism, were the political ideologies primarily chosen

\footnotetext{
${ }^{1}$ A left-right ideological continuum is more appropriate for the study of the Spanish context, where the typically American liberal-conservative continuum may have different connotations (Wojcieszak and Rojas 2011:490).
} 
for our study. Taking into account the political past of Spain, the National Catholic ideology of general Francisco Franco's regime was also added to our analysis. Political leaning (from the far-left to the far-right) and specific political ideologies, as mentioned above, were operationalized to study and codify systematically political-ideological strains. What was coded as "left," "centre-left," etc., does not refer to political groups, or parties, but to the mention of terms such as "left," "centre-left," etc., in the newspapers. On the other hand, it must be pointed out that concepts like "extremism" and "radicalism" have not been used in the same manner in this paper's discussion. Theoretical discussions of extremism/radicalism (March and Mudde 2005, 24-25; Backes 2010, 8-9, 163-167) have led us to use the "extremism" concept to refer primarily, although not solely, to the furthest right positions, whereas "radicalism" is specifically applied in the discussion to characterize an emancipatory left-wing tradition that rejects the structure of contemporary capitalism, but does not necessarily incur in anti-democratic positions.

In order to make the ideological analysis less abstract, specific ideological values were added to our coding scheme: in addition to fundamental values such as freedom, equality, and solidarity/brotherhood (Sunnari 2000,163), cultural values like individualism and collectivism (Triandis 1995, 68-80) were also taken into account.

Given that our aim is to indicate the emphasis on certain ideologies in a stream of messages, frequency analysis was chosen (Krippendorff 2004, 59). Cross-tabulation was not performed, as we do not aim to analyze the statistical relationship between variables. The basic units of the frequency analysis were words ("symbols," in the traditional language of content analysis), whose frequency was computed. The coding sheet also included an evaluative item to ascertain the journalists' general value judgment regarding the coded terms. This is what Lerner et al referred to as "judgment, the way each symbol that occurred was judged favourable, unfavourable, neutral" (1951-1952, 721). Implicit ideologies may be manifested through the way discourse sentences constitute a coherent whole (Van Dijk 1998); hence the final criterion for codifying a "for" or "against" political attitude is the value attributed to a term in the context of the whole opinion article. Thus quantitative analysis identifies and computes terms that represent political ideologies, whereas qualitative analysis goes beyond word frequencies, and takes into account the context of words and expressions in order to evaluate their intended meaning. In our case, text interpretation may be performed by (a) taking into account propositional structures like " $X$ is $P$ "- -being " $X$ " the coded term and "P" a favourable, neutral, or unfavourable description; (b) the use of adjectives; or (c) the interpretation of the whole opinion column as a context unit, whose structure and semantic content could lead the coder to ascertain a value judgment. As Krippendorff points out: "Context units are units that delineate the scope of information that coders need to consult in characterizing the recording units" $(2004,103)$. Thus, coders may take into account when necessary other parts of the text (sentences, paragraphs, or even the whole text) in order to infer the value ascribed to the words recorded.

A four week sample was chosen from the opinion columns published in the most popular digital-native Spanish newspapers in May 2011 to obtain a synchronic image of the main current political trends of the newspapers -a four-week sampling period has been used in other content analysis studies of the press and news media (Graber 1972, 46, 51; Paulussen 2004; Portales E. 2009, 72). Given that May 2011 was a regional and local election period in Spain, this month was chosen on the assumption that newspapers' ideological and political opinions would surface more strongly during an election season, when social life is more politicized than usual. During the spring of 2011, the political climate in Spain was hot, as gossip was rife about the era of Zapatero's leadership clearly coming to an end. The socialist leader did not announce his exit until end of the following July, but tension was already high in the spring due to the chaos threatening to engulf the Spanish economy and the perception that its leader had failed to handle the crisis adequately.

To identify the most relevant online-only generalist newspapers, two databases were used: the Oficina de la Justificación de la Difusión (the Spanish Audit Bureau of Circulations), which tracks and verifies press circulation figures in Spain, and Alexa Web Service, which has already been used as a source for academic research (Steele 2009, 93). The Oficina de 
la Justificación de la Difusión (OJD) search was performed through the OJD website. Several search criteria were used, such as "Noticias e Información" ("News and Information"). Regarding Alexa, we used the keyword "periódico digital" ("digital newspaper") in a search that was restricted to one country (Spain) and one language (Spanish). Both searches were conducted during the first third of 2011. For this study, only original daily news producers were considered newspapers. The initial sample of almost 50 web-only newspapers taken from both the OJD and Alexa was filtered taking into account the Alexa traffic ranking in Spain. Newspapers that ranked below or equal to 4,000 on May 31, 2011 were discarded on the rationale that these media are scarcely read or influential. We also excluded from the list newspapers that did not include generalist themes and sections, newspapers that lacked an opinion section, and those where opinion columns were not clearly located or dated, or were not differentiated from personal weblogs. Table 1 shows the list of online newspapers finally selected.

\begin{tabular}{|c|c|c|c|}
\hline Newspaper & $\begin{array}{l}\text { Online } \\
\text { since }\end{array}$ & URL & \begin{tabular}{|c|} 
Position in \\
Alexa's Traffic Rank
\end{tabular} \\
\hline 1. Libertad Digital & 2000 & www.libertaddigital.es & 85 \\
\hline 2. El Confidencial & 2001 & www.elconfidencial.com & 100 \\
\hline 3. El Confidencial Digital & 2001 & www.elconfidencialdigital.com & 721 \\
\hline 4. El Semanal Digital & 2000 & www.elsemanaldigital.com & 793 \\
\hline 5. La Vozlibre & $\begin{array}{l}\text { No data } \\
\text { available }\end{array}$ & www.lavozlibre.com & 834 \\
\hline 6. Diariocrítico.com & 2004 & www.diariocritico.com & 891 \\
\hline 7. Nació Digital.cat & 2005 & www.naciodigital.cat & 906 \\
\hline 8. El Plural & 2005 & www.elplural.com & 1.101 \\
\hline 9. Vilaweb & 1996 & www.vilaweb.cat & 1.135 \\
\hline 10. MinutoDigital.com & 2004 & www.minutodigital.com & $1.466^{\mathrm{a}}$ \\
\hline 11. Estrella Digital & 1998 & www.estrelladigital.es & 1.667 \\
\hline 12. Diario SIGLO XXI & 2003 & www.diariosigloxxi.com & $1.746^{a}$ \\
\hline 13. Elperiodic.com & 2005 & www.elperiodic.com & 1.793 \\
\hline $\begin{array}{l}14 . \\
\text { Andaluciainformacion.es }\end{array}$ & $\begin{array}{c}\text { No data } \\
\text { available }\end{array}$ & www.andaluciainformacion.es & 2.297 \\
\hline 15. El Imparcial & 2008 & www.elimparcial.es & $2.538^{a}$ \\
\hline 16. La República.es & $\begin{array}{c}\text { No data } \\
\text { available }\end{array}$ & $\overline{\text { www.larepublica.es }}$ & 2.757 \\
\hline 17. República.com & 2010 & www.republica.com & 2.883 \\
\hline 18. Canariasahora.es & $\begin{array}{l}\text { No data } \\
\text { available }\end{array}$ & $\overline{\text { www.canariasahora.com }}$ & 3.580 \\
\hline
\end{tabular}

Table 1: Top online-only Spanish newspapers by traffic at $31^{\text {st }}$ May 2011

${ }^{\text {a }}$ The traffic ranks of the Diario Siglo XXI and Minuto Digital newspapers were consulted on June 10th, 2011, while EI Imparcial's rank was consulted on June 2nd, 2011.

The political orientation and editorial lines of the top online-only Spanish newspapers by traffic is not transparent. That is, most outlets do not explicitly declare a political orientation and they do not have editorial columns, but only opinion sections. However, the majority of them fit into the Spanish polarized model due to their clear political positioning on one side of the Spanish political spectrum. At least the top five, as well as Minuto Digital and El Imparcial, are the harshest critics of left-leaning political views and parties. However, a global ideological analysis of online-only newspapers in Spain is missing. This paper aims to address that void.

A sample of 434 opinion articles was selected amongst all the individual opinion columns that were gathered initially by the researchers. Given that the number of individual columns 
published by each newspaper differs greatly, two sampling criteria were applied: in the case of newspapers that publish a scarce number of columns (such as Vilaweb or La República.es), most columns from May 2011 were selected. In the case of outlets with a strong opinion section, a systematic random sampling was performed, with different $k$ intervals (Krippendorff 2004, 115) that were applied in order to obtain similar samples throughout the newspapers whenever possible. Hence, and with the exceptions of El Confidencial Digital (26 columns), Vilaweb (10), El Periodic.com (28), Minuto Digital (20), Andaluciainformación.es (13), Diariocrítico.com (12), and La República.es (6), 29 columns were provided by each newspaper in most of the cases.

Codification was performed by three post-graduate students. Several intercoder agreement tests were carried out, with different coders, throughout the methodological design. As a result, the coding sheet was progressively refined and improved until a 0.83 two-coder agreement was attained by using Krippendorf's $\alpha$. The 0.83 reliability level was attained for all items. Reliability coefficient met normal content analysis standards (Hoffman 2006, 65).

\section{Results}

\subsection{Main topic: domestic politics}

Before addressing the representation of the ideologies, we quantified the analyzed columns according to their themes, to determine whether or not they were related to ideologicalpolitical issues. The list of topics was adapted from Gisselquist and Lawson (2006).

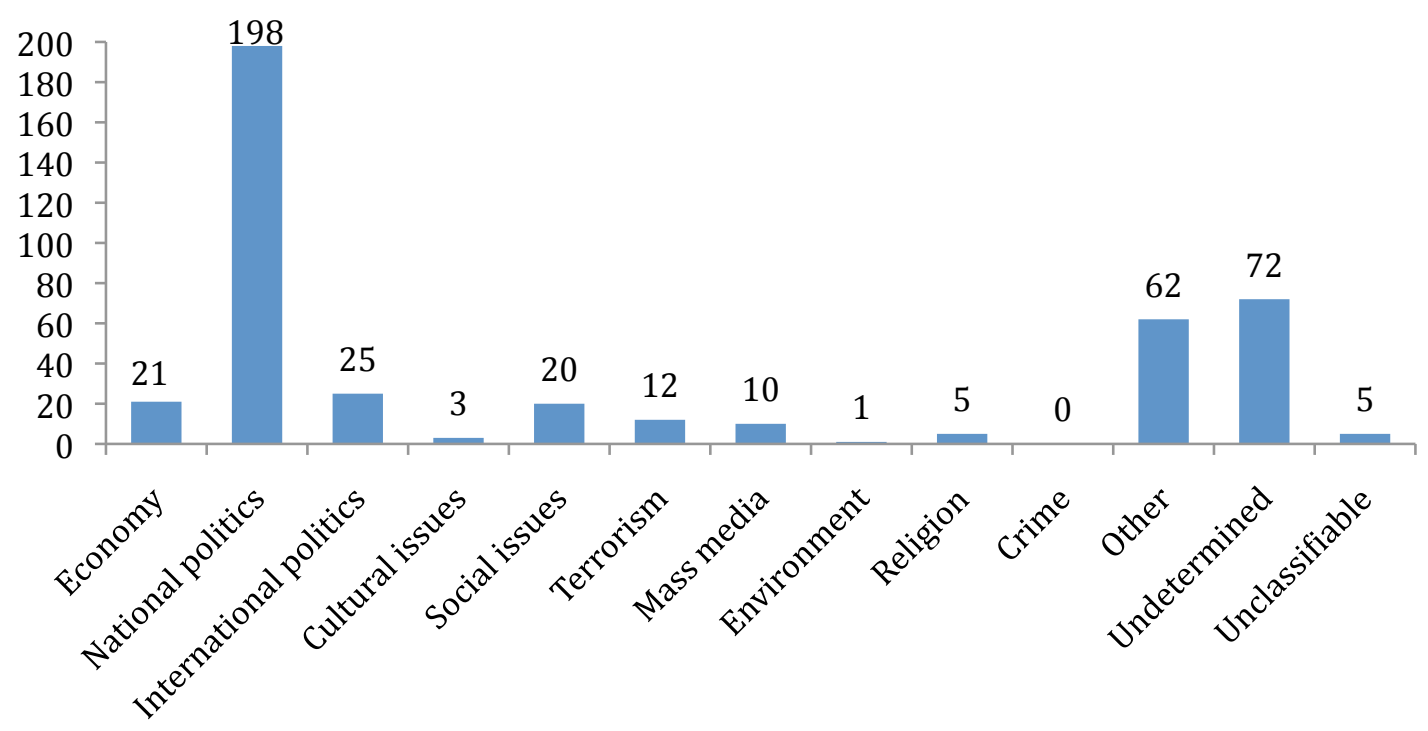

Figure 1: Main Topics Frequencies

As shown in Figure 1, of the 434 opinion columns analyzed, nearly half dealt with issues of national policy. Therefore we found averages of opinion that were highly concentrated on particular political issues $(M=33.38, S D=54.40)$. Domestic politics figuring so dominantly in the opinion pages of our sample is consistent with the fact that the period we studied was a regional and local election season in Spain. After national politics, the most commented topics-international politics, the economy, and social issues-appear with a much lower frequency. For many of the articles, it was impossible to determine the theme, or they were themes that fell outside of our codification criteria. 


\subsection{Main focus: general issues and current affairs}

Secondly, we identified the subject of the information, to see if a particular person or event captured media attention in such a way that could undermine the analysis.

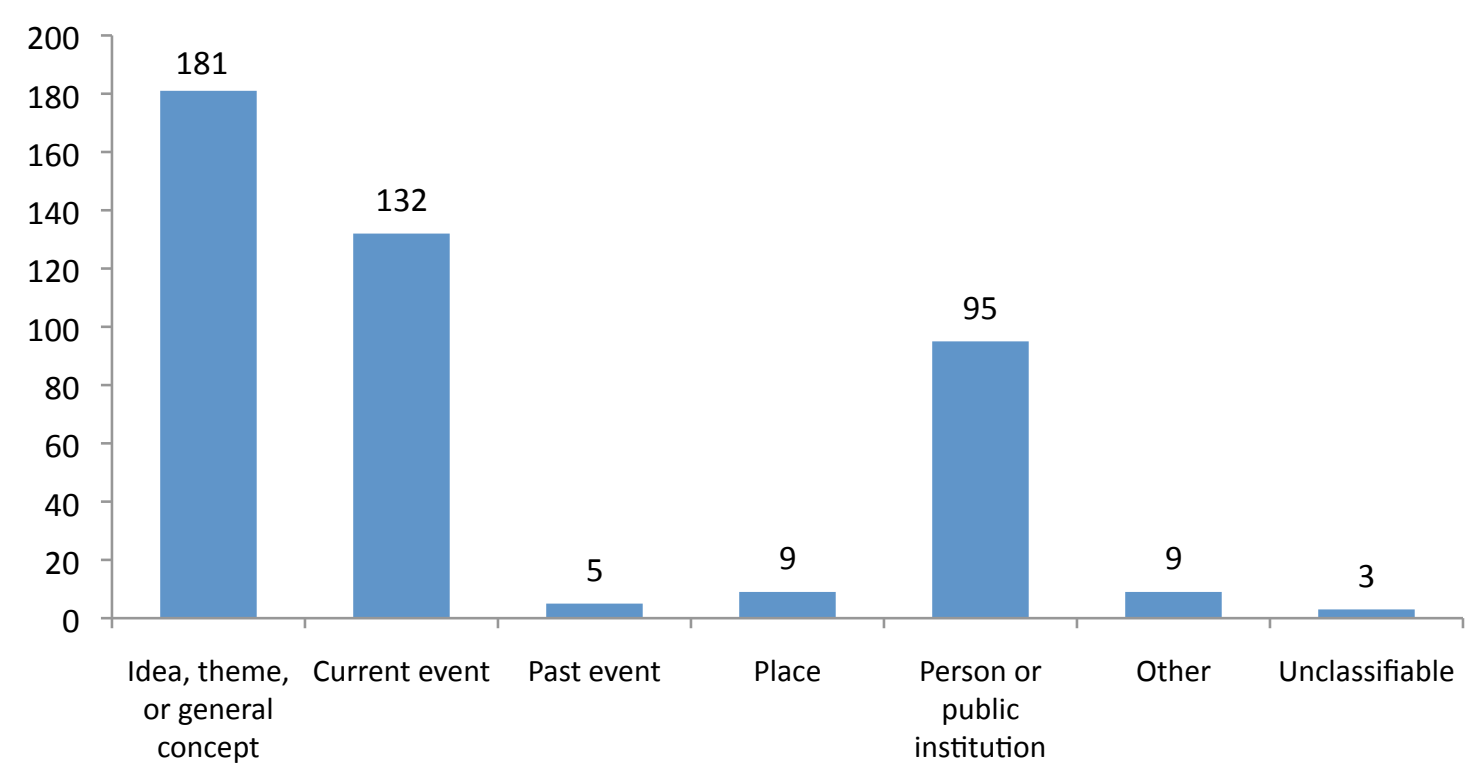

Figure 2: Information subject frequencies.

Figure 2 shows that 181 articles in the sample focus on an idea, theme or concept. This is important because it indicates that Spanish online opinion discusses primarily, and repeatedly, generic issues, which can be classified into the field of political ideologies. One hundred and thirty-two articles deal with a specific current event, and the third largest group of columns (95) refers to a person or a public institution.

\subsection{Ideological spectrum: the right-wing has a higher frequency of positive or neutral mentions than the left-wing}

In general, it should be emphasized that the representation of ideologies within the left-right ideological spectrum tends to be neutral $(M=30)$, compared to a very low average of negative mentions $(M=3.28)$. The average of negative opinions on the radical left-extreme right political spectrum is higher $(M=17.4)$, which may indicate that the online Spanish press tries to position itself as critical of ideologies. In any case, references to ideological spectrum identified in the columns $(M=50.71, S D=71.03)$ mainly refer to the left (51 percent) and to the right (35 percent). The next most mentioned references correspond to the extreme right (22 mentions) and the radical left (12 mentions).

With respect to how the press mentions the left, Table 2 shows that while most of the entries are neutral (67 percent of all cases), there is no positive mention. The remaining mentions of the ideological left all have negative connotations (33 percent of cases). This is striking because the newspapers that most mention the left are the pro-free market publication El Confidencial and the progressive daily El Plural. When considering the references to the right, most mentions are also neutral (48 percent), followed by negative (33 percent). But here we identified that almost 19 percent of the mentions had positive connotations. In other words, the frequencies indicate that the left is never represented positively, while the right does receive favorable coverage. One example of this kind of coverage was found in an opinion article from El Confidencial, whose writer argues that the political left is using strategically the "[...] miedo a la derecha[...]" ("[...] fear of the right[...]") (Quevedo 2011; italics in the original), adding that the Partido Socialista Obrero Español (Spanish Socialist Workers' Party) blames the conservative administration of former Spanish Prime Minister José María Aznar for un- 
employment. Immediately, the writer ironically notes that the by-then Prime Minister, José Luis Rodríguez Zapatero "[...] presume de haber conseguido la tasa más baja de paro en 2007, gracias precisamente ja las políticas de Aznar!" (“[...] boasts of having achieved the lowest unemployment rate in 2007, thanks precisely to Aznar's policies!") (Quevedo 2011). Mentions of the extreme left and the extreme right also receive unequal treatment: if 75 percent of the mentions of the extreme left are negative, in the case of the extreme right the negative mentions are 46 percent. The extreme right is treated much more neutrally (55 percent of mentions) than the radical left (25 percent). The centre, centre-left and centre-right are barely mentioned ( 5 percent), and in the few cases where they are, the connotation is never positive.

\begin{tabular}{lcccc}
\hline Ideological spectrum & Mentions & Positive & Negative & Neutral \\
\hline Extreme left & 12 & 0 & 9 & 3 \\
& $(3.3 \%)$ & $(0.0 \%)$ & $(75.0 \%)$ & $(25.0 \%)$ \\
Left & 180 & 0 & 60 & 120 \\
Centre-left & $(50.7 \%)$ & $(0.0 \%)$ & $(33.3 \%)$ & $(66.7 \%)$ \\
& 3 & 0 & 0 & 3 \\
Centre & $(0.8 \%)$ & $(0.0 \%)$ & $(0.0 \%)$ & $(100.0 \%)$ \\
& 7 & 0 & 1 & 6 \\
Centre-right & $(1.9 \%)$ & $(0.0 \%)$ & $(14.3 \%)$ & $(85.7 \%)$ \\
& 8 & 0 & 1 & 7 \\
Right & $(2.2 \%)$ & $(0.0 \%)$ & $(12.5 \%)$ & $(87.5 \%)$ \\
& 123 & 23 & 41 & 59 \\
Extreme right & $(34.6 \%)$ & $(18.7 \%)$ & $(33.3 \%)$ & $(48.0 \%)$ \\
& 22 & 0 & 10 & 12 \\
Total & $(6.1 \%)$ & $(0.0 \%)$ & $(45.5 \%)$ & $(54.5 \%)$ \\
\hline
\end{tabular}

Table 2: Frequency of mentions of positions on the ideological spectrum

From the data collected on frequency, a tendency within online newspapers begins to emerge. Online journalism can be defined, not so much by the ideas they publish as by the ideas they attack. For example, the publication that most mentions the left is the ultraconservative Minuto Digital (7 mentions) while the newpaper that most mentions the extreme right is the progressive El Plural. At the same time, the newspaper that most mentions the left (47 mentions, that is 26.1 percent of the total mentions) is El Semanal Digital, which is a libertarian-conservative publication (Almiron 2006:26-28).

\subsection{Ideological values: freedom has the highest frequency}

Table 3 centres on specific ideological values. Here we note that, generally, the average of positive mentions $(M=17.5)$ is higher than both negative $(M=1.5)$ and neutral mentions $(M$ $=12.16)$. 


\begin{tabular}{lcccc}
\hline Ideological values & Mentions & Positive & Negative & Neutral \\
\hline Freedom & 127 & 76 & 1 & 50 \\
& $(67.9 \%)$ & $(59.8 \%)$ & $(0.8 \%)$ & $(39.4 \%)$ \\
Equality & 8 & 7 & 1 & 0 \\
& $(4.2 \%)$ & $(87.5 \%)$ & $(12.5 \%)$ & $(0.0 \%)$ \\
Solidarity & 14 & 8 & 0 & 6 \\
& $(7.4 \%)$ & $(57.1 \%)$ & $(0.0 \%)$ & $(42.9 \%)$ \\
Brotherhood & 4 & 3 & 0 & 1 \\
& $(2.1 \%)$ & $(75.0 \%)$ & $(0.0 \%)$ & $(25.0 \%)$ \\
Individualism & 19 & 5 & 5 & 9 \\
& $(10.1 \%)$ & $(26.3 \%)$ & $(26.3 \%)$ & $(47.4 \%)$ \\
Collectivism & 15 & 6 & 2 & 7 \\
& $(8.0 \%)$ & $(40.0 \%)$ & $(13.3 \%)$ & $(46.7 \%)$ \\
\hline \multirow{2}{*}{ Total } & 187 & 105 & 9 & 73 \\
& & $(56.1 \%)$ & $(4.8 \%)$ & $(39.0 \%)$ \\
\hline
\end{tabular}

Table 3: Frequency of mentions of ideological values

Of all of the values we coded, freedom is the one that appears with the highest and most dominant frequency, gathering 68 percent of all mentions. Furthermore, the concept of freedom is mentioned positively the majority of the time (60 percent of all cases) or at least neutrally (39 percent). Only one negative mention of this value was found in the sample. It is noteworthy that freedom is positively valued in libertarian oriented publications (El Imparcial, Libertad Digital) as well as in patriotic right-wing publications (Minuto Digital). The other most-mentioned values in the articles of the sample are mentioned with far less frequency than freedom: individualism (10 percent), collectivism (8 percent), or solidarity (7 percent). The dominant connotations are neutral in the case of collectivism and individualism, and positive in the case of solidarity. Solidarity is also neutrally represented, as in one column from Diariocritico.com that lists this value amongst other things that were being asked for by young people in Spain (Del Olmo 2011). However, even though solidarity is never mentioned negatively, collectivism receives two negative mentions. It is perhaps more significant that individualism is mentioned negatively as much as it is positively (26 percent of the case in both times). Of all of the ideological values, only individualism and collectivism do not have a frequency of dominant mentions with positive connotations.

\subsection{Specific political ideologies: left-wing ideologies accumulate the highest frequency of negative mentions}

As for references to specific ideologies within the political spectrum, it is noteworthy that the average number of mentions of terms that define these ideologies is high $(M=42.27)$, although the mentions are fewer than those terms that refer to the left-right spectrum. Moreover, the high level of dispersion found in the specific ideologies variable $(S D=70.23)$ shows that online journalism focuses its attention on very few policy issues. For the total number of ideologies codified (Table 4), four hundred and sixty-five mentions were identified. Amongst these, socialism stands out, accumulating more than half of all of the mentions (54 percent). The second most mentioned political ideology was communism (9 percent) and the third was Francoism/National Catholicism (7 percent). 


\begin{tabular}{lcccc}
\hline Specific political ideologies & Mentions & Positive & Negative & Neutral \\
\hline Anarchism / left-wing liber- & 18 & 0 & 8 & 10 \\
tarianism & $(3.8 \%)$ & $(0.0 \%)$ & $(44.4 \%)$ & $(55.6 \%)$ \\
& 41 & 0 & 28 & 13 \\
Communism & $(8.8 \%)$ & $(0.0 \%)$ & $(68.3 \%)$ & $(31.7 \%)$ \\
& 251 & 14 & 86 & 151 \\
Socialism & $(53.9 \%)$ & $(5.6 \%)$ & $(34.3 \%)$ & $(60.2 \%)$ \\
& 21 & 11 & 2 & 8 \\
Social democracy & $(4.5 \%)$ & $(52.4 \%)$ & $(9.5 \%)$ & $(38,1 \%)$ \\
& 2 & 0 & 1 & 1 \\
Christian democracy & $(0.4 \%)$ & $(0,0 \%)$ & $(50.0 \%)$ & $(50.0 \%)$ \\
& 17 & 1 & 5 & 11 \\
Liberalism / neoliberalism / & $(3.6 \%)$ & $(5.9 \%)$ & $(29.4 \%)$ & $(64.7 \%)$ \\
laissez-faire & 7 & 0 & 4 & 3 \\
Right-wing libertarianism / & $(1.5 \%)$ & $(0.0 \%)$ & $(57.1 \%)$ & $(42.9 \%)$ \\
anarcho-capitalism & 31 & & & 18 \\
Conservatism / libertarian & $(6.6 \%)$ & $(19.4 \%)$ & $(22.6 \%)$ & $(58.1 \%)$ \\
conservatism / neoconser- & 35 & 0 & 17 & 18 \\
vatism & $(7.5 \%)$ & $(0.0 \%)$ & $(48.6 \%)$ & $(51.4 \%)$ \\
Nacional Catholicism / & 29 & 0 & 26 & 3 \\
Francoism & $(6.2 \%)$ & $(0.0 \%)$ & $(89.7 \%)$ & $(10.3 \%)$ \\
Fascism & 13 & 0 & $(61.5 \%)$ & $(38.5 \%)$ \\
\hline Nazism & $(2.7 \%)$ & $(0.0 \%)$ & 192 & 241 \\
\hline Total & 465 & $(6.9 \%)$ & $(41.3 \%)$ & $(51.8 \%)$ \\
\hline
\end{tabular}

Table 4: Frequency of mentions of specific political ideologies

The only ideology that receives a positive mention, by majority, is social democracy (52 percent of all mentions had a positive characterization). The rest of the ideologies had neutral or negative connotations. Communism was the political ideology that received the most negative valoration (68 percent of negative mentions) - one example can be found in a column published in Libertad Digital, that refers to "[...] un sistema criminal como el comunismo [...]" ("[...] a criminal system like communism [...]" (Rodríguez Braun 2011). Rightist totalitarian ideologies (Francoism, fascism, and Nazism) do not receive any positive mentions, and they are represented essentially in a negative way, with one exception: Francoism or Spanish National Catholicism. While fascism is mentioned in a way that is clearly negative, in 90 percent of the cases, and Nazism in 61 percent of the cases, Francoism receives more neutral mentions (51 percent) than negative ones (49 percent).

Non-totalitarian right-wing ideologies receive an uneven treatment in the study sample. While anarcho-capitalism is barely mentioned, and in no case positively so, conservatism is mentioned in a positive way on 6 occasions. On 7 occasions it receives a negative mention, and on 18 occasions it is mentioned in a neutral way. On the left or centre-left we observe a much higher frequency of negative mentions. Socialism is mentioned neutrally in 60 percent of the cases and positively in 6 percent of the cases, but the rest (34 percent) corresponds to negative opinions, which in absolute terms implicates up to 86 concrete mentions. Of all of the political ideologies, socialism is the one that obtains the most negative mentions in abso- 
lute terms, which supposes 45 percent of all of the negative mentions in relative terms. The next ideology with the most negative mentions is communism (it receives 15 percent of all of the negative mentions regarding concrete ideologies). Anarchism or left-wing libertarianism receives few mentions. The connotations are neutral or negative in almost equal parts, which is a similar distribution to that of right-wing libertarianism. Yet right-wing libertarianism has only 7 mentions, while left-wing libertarianism is mentioned 18 times in the sample. The rest of the ideologies, from the centre or the centre-right, receive few mentions in general terms. In total, social democracy and Christian democracy are mentioned 23 times (5 percent of all of the mentions), of which 21 mentions are for social democracy and 2 are for Christian democracy.

In general we observe a clear bias in references to ideological values, with numerous references to ideologies on the left (67 percent) and on the right or the extreme right (28 percent). But there is a minimal presence of references to the ideological centre. Negative assessments are polarized in a similar manner: ideologies on the left receive 64 percent of the total negative valuations, while ideologies on the right or extreme right receive 27 percent. The tendency of portraying rival ideologies in a negative way is not unique to the right, as there are also progressive publications such as El Plural and Vilaweb which do not provide positive ratings to any ideologies and are very critical of fascist ideology.

\section{Discussion}

Spanish media is highly polarized and audiences have strong ties to their chosen media outlets according to their ideological loyalties. In this sense, our data generally agree with Hallin and Mancini's polarized pluralist model, which is characterized by a high level of politicization (2004, 298). Our findings are also consistent with the idea that Spanish media are partisan (Sampedro and Seoane Perez 2008:337-338). Our results suggest that the internet produces even further polarization, with more biased and unbalanced media coverage than that found offline. Such polarization is consistent with Sunstein's observation about the link between the internet, group polarization, and extremism (Sunstein 2001, 65, 71).

In the context of conservative or reactionary newspapers in the top-ranking digital-native media in Spain, our data indicates a negative representation of leftist ideologies. This antileftism would be the main answer to our first research question on how to define online-only Spanish journalism with regard to ideology. From a more global perspective, the role of attacking the left that the Spanish cybermedia play reflects the anti-Democrat bias of American news sites like WorldNetDaily or FrontPage (Brock 2005, 102, 159-161). In the Spanish context, this tendency to negatively represent the left could also be interpreted as the result of the predominance of right-wing newspapers in cyberspace. In that sense, our data are consistent with Almiron's thesis (2006) on the conservative tendencies of Spanish digital newspapers. Also from a contextual point of view, the interpretation of our data must take into account the recent emergence in Spain of media with an extreme right bias (Gómez 2010, González-Harbour 2010). On the other hand, it must be pointed out that, in the context of the political economy of communication's framework, the right-leaning of the newspapers could be interpreted as an ideological bias in itself. From this point of view, Spanish online-only newspapers may be understood as media that help maintain the status quo.

Simultaneously, the high number of neutral mentions, when referring to specific ideologies as well as regarding the political spectrum in general, indicates that, with the exception of social democratic positions, the Spanish online media aims to focus ideological positioning indirectly. For example, we found that even though a column may be anti-left, it does not stand out for making positive valuations of rightist ideas. This is remarkable in a study that includes clearly ideological newspapers like Libertad Digital (Díaz Noci 2005, 35), and may indicate a generalized journalistic trend where ideological activism hides behind a façade of alleged apoliticism. Nonetheless, in regard to specific ideological stances that could be inferred in the case of individual news outlets, some newspapers seem to be more right wing than others. For example, Vilaweb and El Plural are progressive publications that criticize the right (and, more specifically, the extreme right), whereas Libertad Digital is sympathetic to 
conservatism and/or libertarian conservatism. Surprisingly, El Imparcial tends to represent social-democracy favourably, whereas Minuto Digital criticizes different left-wing ideologies. Right-wing positions could also be inferred from El Confidencial's and El Confidencial Digital's columns. Pinning down other specific outlets is more difficult, as it is the case with El Semanal Digital, whose opinion seems to veer between right-wing and social-democratic positions. In other cases, no clear ideological stance can be inferred-or even guessedfrom digital newspapers. Such fuzziness is in line with the aforementioned trend towards indirect ideological positioning.

The issue of extremism is another interesting point for discussion. The answer to our second research question (concerning the extent to which extreme positions are represented in opinion journalism) is ambiguous. On the one hand, the extreme political ideologies of both the left and right received negligible positive mentions. On the other hand, it is striking that neutral mentions of extreme right positions outnumber those of negative mentions, while negative mentions of the radical left triple neutral mentions. Moreover, it is interesting to note that the issue of extremism-on the right and on the left-is a quantitatively more relevant theme than centrist ideological positions. In short, the online-only Spanish press seems to want to project an attitude of neutrality when it comes to ideology, but there is actually a more generous attitude toward right-wing extremism when compared to the left. Dahlgren notes that "for its users, the Net can expand the political margins of the public sphere" (2001:48). Our study indicates that it is the margins on the right which have greater potential in the Spanish context. We cannot overlook, after all, that the third most mentioned political ideology in the columns is Spanish National Catholicism.

The anti-progressive bias of Spanish digital-native journalism opens several interesting lines of inquiry. From a technological point of view, digital media-because of its ability to yield to the urgency of immediacy and dispel deeper reflection (Fenton 2010)—would help to accentuate the traditional political struggle of the Spanish media as a whole, even if rather unevenly. As to the economic factor, it is possible that the success of conservative or ultraconservative proposals in the digital-native press has to do with a greater capacity for ideological projects of this bias to attract investors to their websites. Again, the features of the polarized pluralist model, typical in Spain, would play an important role. The traditional ties between journalists and political actors (Hallin and Mancini 2004) could also mean easier access to funding sources for conservative media, in the measure that rightist politics is better connected to the economic and financial sectors.

Another interesting point of discussion is the relationship of the Spanish audience to political ideologies. From an ideological standpoint, the Spanish show a higher degree of leftism compared to other Europeans (as evidenced by the European Social Survey 2008; Martín $2010,18)$. Yet citizens who hold progressive positions are fragmented when compared to those who identify as conservative. The conservatives are essentially united around a single political party at the national level. This social reality is reflected to some extent in our data, which indicate a high statistical dispersion in the representation of political ideologies and values, which can be interpreted in terms of the absence of real diversity in the online press. In other words, Spanish online opinion journalism focuses most of its views on a handful of political positions. The concentration of the Spanish political right may also be related to the fact that the average frequency of mentions of the terms of the left-right political spectrum is greater than the average frequency of mentions of specific ideologies. Rather than developing a journalistic discourse which analyzes particular ideological variants on the right (libertarianism, conservatism, etc.), online journalism seems to employ a more vague term, "the right," lumping together diverse ideological "families"-which could even become, at times, contradictory.

Finally, the negative portrayal of socialism could be due to the ability of libertarian and conservative communities to adapt to the new digital medium. This would explain the fact that the most-read digital-native publications such as Libertad Digital or El Confidencial, are also the most long-standing on the internet in Spain. Even though technologically enthusiastic writers come from diverse ideological backgrounds, the fact remains that some of the biggest promoters of the libertarian "myth" about the internet come from conservative or ultra- 
conservative spheres (Almiron and Jarque 2008). In this context, and also taking into account the importance the ideological value of "freedom" receives in our study, it appears that in Spain the digital journalism that is taking shape is biased towards promoting the libertarian right. At the same time, the fact that the opinion columns do not openly embrace individualism, in an absolute form, may indicate that the statist-collectivist tradition of the Spanish right still has echoes in today's journalism.

\section{Conclusions}

In a highly politicized and polarized media landscape, online-only opinion journalism plays a role in the depiction of ideologies and values that relate to the political context of Spain. Opinion columns openly embrace the discussion of ideas, and tend to be centred on Spanish domestic politics. The Spanish digital media fit a model where newspapers emphasize commentary directed at political activists. It may be assumed that such web activism is mainly of an anti-left, right-wing variety, with conservative or very conservative ideologies being cherished by Spanish opinion journalism. This conclusion mirrors the ideological bias of the offline press landscape in Spain, where cultural and fiscal conservatism is the most represented point of view in mainstream newspapers. More specifically, and taking into account that freedom is the predominant ideological value, an implicit right-libertarian pattern seems to emerge in the Spanish digital media landscape.

Our study depicts a right-leaning journalism defined by what it rejects, not by what it believes. On the other hand, it tries to be neutral when referring to specific political or ideological positions. At the same time, Spanish digital journalism does not try to be neutral regarding values, such as freedom, equality, or solidarity. Therefore, the Spanish digital-native newspaper sector seems to be politically polarized, but tries to avoid a clear-cut representation of ideological positions-a representation which tends not to be explicit in terms of classical ideologies such as socialism, conservatism, or laissez-faire. More specifically, these newspapers do not try to depict extreme ideologies in a positive light; however, issues related to ideological extremism are part of the debate. Ironically, the study of digital newspapers brings to light an apparently post-ideological scenario where issues that come from the 1930s and the Spanish Civil War-such as anti-communism, National Catholicism, or the extreme right-reappear in cyberspace.

Like any study, ours has limitations, and suggests new lines of research. For example, further research is needed to study the treatment these newspapers give to specific ideological themes and issues related to economic and socio-cultural questions, such as unemployment, taxes, or abortion. In addition to that, studying the political bias of such politicized digital media becomes increasingly relevant. In other words, a more detailed study of the way onlineonly newspapers perform specific ideological functions and depict specific Spanish political parties, may be relevant for the discussion of theoretical topics about the political implications of the new digital media.

\section{References}

Allan, Stuart. 2009. Online News. Maidenhead, Berkshire: Open University Press.

Almiron, Núria. 2006. Pluralismo en Internet: El Caso de los Diarios Digitales Españoles de Información General sin Referente Impreso. Ámbitos. Revista Internacional de Comunicación 15: 9-31.

Almiron, Núria, and José Manuel Jarque. 2008. El mito digital. Barcelona: Anthropos.

Althusser, Louis. 1971. Ideology and Ideological State Apparatuses. In Lenin and Philosophy and Other Essays, 127-188. London: New Left Books.

Backes, Uwe. 2010. Political Extremes. London and New York: Routledge.

Berelson, Bernard. 1971. Content Analysis in Communications Research. New York: Hafner.

Biography of David Horowitz. FrontPageMagazine.com. Accessed September 5, 2011. http://frontpagemag.com/biography/

Brock, David. 2005. The Republican Noise Machine. New York: Three Rivers Press.

Casasús, Josep Maria. 1985. Ideología y Análisis de Medios de Comunicación. Barcelona: Mitre. 
Checa Godoy, Antonio. 2011. Prensa y Partidos Políticos durante la II República. Sevilla: Centro Andaluz del Libro.

Chomsky, Noam, and Edward S. Herman. 2002. Manufacturing Consent: The Political Economy of the Mass Media. New York: Pantheon Books.

Chomsky, Noam. 1989. Necessary Illusions: Thought Control in Democratic Societies. Boston, MA: South End Press.

Chomsky, Noam. 2002. Media Control. The Spectacular Achievements of Propaganda. New York: Seven Stories Press.

Curran, James and Tamara Witschge. 2010. Liberal Dreams and the Internet. In New Media, Old News, edited by Natalie Fenton, 102-118. London: Sage.

Curran, James. 2005. Media and Power. London: Routledge.

Dahlgren, Peter. 2001. The Public Sphere and the Net: Structure, Space, and Communication. In Mediated Politics, edited by W. Lance Bennett and Robert M. Entman, 33-55. Cambridge: Cambridge University Press.

Day, Anita G., and Guy Golan. 2005. Source and Content Diversity in Op-Ed Pages: Assessing Editorial Strategies in The New York Times and the Washington Post. Journalism Studies 6 (1): 61-71.

Del Olmo, Luis. 2011. Mayo y los Jóvenes. Diariocrítico.com, May 18. Accessed October 9, 2013. http://www.diariocritico.com/noticias/271419

Díaz Noci, Javier. 2005. Historia de los Cibermedios en España. In Cibermedios, edited by Ramón Salaverría, 21-38. Sevilla: Comunicación Social Ediciones y Publicaciones.

Doyle, Gillian. 2002. Media Ownership: The Economics and Politics of Convergence and Concentration in the UK and European Media. London: Sage.

Eagleton, Terry. 2007. Ideology. An Introduction. London: Verso.

Fenton, Natalie. 2010. New Media, Old News. Journalism and Democracy in the Digital Age. Thousand Oaks, CA: Sage.

Garnham, Nicholas. 1986. Contribution to a Political Economy of Mass-Communication. In Media, Culture \& Society. A Critical Reader, edited by Richard Collins, James Curran, Nicholas Garnham, Paddy Scannell, Philip Schlesinger and Collin Sparks, 9-32. London: Sage.

Gaskins, Benjamin, and Jennifer Jerit. 2012. Internet News: Is It a Replacement for Traditional Media Outlets? The International Journal of Press Politics 17 (2): 190-213.

Gillmor, Dan. 2006. We the Media. Grassroots Journalism by the People, for the People. Sebastopol, CA: O'Reilly.

Girauta, Juan Carlos. 2007. La Eclosión Liberal. Madrid: Martínez Roca.

Gisselquist, Rachel, and J. Chappell H. Lawson. 2006. Preliminary findings from content analysis of television spots in Mexico's 2006 presidential campaign. Mexico 2006 Panel Study, August 2006. Accessed June 19, 2013, from http://web.mit.edu/clawson/www/polisci/research/mexico06/ContentAnalysis--ads.doc

Golding, Peter and Graham Murdock. 1996. Culture, Communications and Political Economy. In Mass Media and Society, edited by James Curran and Michael Gurevitch, 11-30. London: Arnold.

Gómez, Rosario G. 2010. Los 'Ultras' Conquistan la TDT. El País, February 22, 30-31.

González Harbour, Berna. 2010. Ojo con la Derecha sin Complejos. In El País, February $22,31$.

Graber, Doris A. 1972. Personal Qualities in Presidential Images: The Contribution of the Press. Midwest Journal of Political Science 16 (1): 46-76.

Hall, Stuart. 1973. Encoding and decoding in the Television Discourse. CCCS Stencilled Paper n. 7 , Birmingham: Centre for Contemporary Studies.

Hall, Stuart. 1982. The Rediscovery of 'Ideology': Return of the Repressed in Media Studies. In Culture, Society, and the Media, eds. Michael Gurevitch, Tonny Bennett and James Curran, 52-86. London: Methuen.

Hall, Stuart. 1996. Culture, Media, Language: Working Papers in Cultural Studies, 1972-1979 (Cultural Studies Birmingham). London: Routledge.

Hallin, Daniel, and Paolo Mancini. 2004. Comparing Media Systems. Three Models of Media and Politics. New York: Cambridge University Press.

Heywood, Andrew. 2007. Political Ideologies. An Introduction. 4th edition. Basingstoke (Hampshire), and New York: Palgrave Macmillan.

Hoffman, Lindsay H. 2006. Is Internet Content Different after All? A Content Analysis of Mobilizing Information in Online and Print Newspapers. Journalism \& Mass Communication Quarterly 83 (1): 58-76. 
Holsti, Ole R. 1969. Content Analysis for the Social Sciences and Humanities. Reading, MA: AddisonWesley.

Krippendorff, Klaus. 2004. Content Analysis: An Introduction to Its Methodology. London: Sage.

Lerner, Daniel, Ithiel Pool, and Harold D. Lasswell. 1951/1952. Comparative Analysis of Political Ideologies: A Preliminary Statement. The Public Opinion Quarterly 15 (4): 715-733.

March, Luke, and Cas Mudde. What's Left of the Radical Left? The European Radical Left After 1989: Decline and Mutation. Comparative European Politics 3 (1): 23-49.

Martín, Carolina. 2010. Los Españoles siguen a la Izquierda de Europa. Público, June 20, 18-19.

Mcknight, David. 2003. A World Hungry for a New Philosophy: Rupert Murdoch and the rise of neoliberalism. Journalism Studies 4 (3): 347-358.

Mújica, Jorge Enrique. Entrevista con Eulogio López, fundador y director de hispanidad.com. Catholic.net . Accessed September 19, 2011. http://es.catholic.net/comunicadorescatolicos/477/746/articulo.php?id=33165

Nosotros. Rebelión. Accessed September 8, 2011. http://www.rebelion.org/nosotros.php

Paulussen, Steve. 2004. Online News Production in Flanders: How Flemish Online Journalists Perceive and Explore the Internet's Potential. Journal of Computer-Mediated Communication 9 (4). Accessed November 10, 2012, from: http://onlinelibrary.wiley.com/doi/10.1111/j.10836101.2004.tb00300.x/full

Pineda, Antonio. 2009. Algunas Implicaciones de la Teoría de la Economía Política de la Comunicación para la Investigación de la Propaganda. RLCS, Revista Latina de Comunicación Social, 64: 553-562. Accessed November 10, 2012, from: http://www.revistalatinacs.org/09/art/45 844 ULEPICC 03/36Pineda.html

Portales E., Juan Cristóbal. 2009. A Test of Personalization of Politics in Chile's 2009 Presidential Election. Cuadernos de Información 25 (II): 69-82.

Quevedo, Federico. 2011. ¡Menos mal que está el PP para Echarle la Culpa de todo! El Confidencial, May 10. Accessed October 10, 2013. http://www.elconfidencial.com/dos-palabras/2011/menosecharle-culpa-20110510-7348.html

Reig, Ramón and Aurora Labio. 2006. Propuestas de comunicación alternativa en Internet: Los casos de Hispanidad, Minuto Digital y Rebelión. Razón y Palabra 49. Accessed November 10, 2012, from:

http://www.razonypalabra.org.mx/anteriores/n49/bienal/Mesa\%201/Reig\%20y\%20Labio\%HISPANI DAD.pdf

Reig, Ramón. 2004. Dioses y diablos mediáticos: cómo manipula el poder a través de los medios de comunicación. Barcelona: Urano.

Rodríguez Braun, Carlos. 2011. Carrillo social. Libertad Digital, May 1. Accessed October 9, 2013. http://www.libremercado.com/2011-05-01/carlos-rodriguez-braun-carrillo-social-59514/

Ríus Sanchis, Inmaculada. 2000. La imagen del imperio, o la justificación del imperio en imágenes. A propósito de Le Petit Journal Illustré (1890-91). In Propaganda impresa y construcción del estado moderno y contemporáneo edited by Carmen Espejo Cala, 59-71. Sevilla: Alfar.

Sampedro, Víctor, and Francisco Seoane Pérez. 2008. The 2008 Spanish General Elections: "Antagonistic Bipolarization" Geared by Presidential Debates, Partisanship, and Media Interests. The International Journal of Press/Politics 13 (3): 336-344.

Sánchez González, María. 2008. Cibermedios de acceso abierto con información confidencial en España como nueva modalidad de confidencialismo online. Zer 13 (24): 157-181.

Schiller, Herbert I. 1973. The Mind Managers. Boston: Beacon Press.

Seider, Maynard S. 1974. American Big Business Ideology: A Content Analysis of Executive Speeches. American Sociological Review 39: 802-815.

Smith Pussetto, Cintia, Nancy Janett García Vázquez, and Jesús David Pérez Esparza. 2008. Análisis de la ideología empresarial regiomontana. Un acercamiento a partir del periódico El Norte. CONFines de Relaciones Internacionales y Ciencia Política 4 (7): 11-25.

Stanyer, James. 2009. Web 2.0 and the Transformation of News and Journalism". In Routledge Handbook of Internet Politics, eds. Andrew Chadwick and Philip Howard, 201-213. New York: Routledge.

Steele, Janet. 2009. Professionalism Online. How Malaysiakini Challenges Authoritarianism. International Journal of Press/Politics 14 (1): 91-111.

Sunnari, Vappu. 2000. United Nation's Human Rights Documents as the Value Basis for the Teacher's Work. In Ethical Challenges for Teacher Education and Teaching. Special Focus on Gender and 
Multicultural Issues, edited by Vappu Sunnari and Rauni Räsänen, 160-167. Oulu: University of Oulu.

Sunstein, Cass. 2001. Republic.com. Princeton and Woodstock: Princeton University Press.

Taiwo, Rotimi. 2007. Language, Ideology and Power Relations in Nigerian Newspaper Headlines. Nebula 4 (1): 218-245.

Tower Sargent, Lyman. 1996. Contemporary Political Ideologies. A Comparative Analysis. Tenth Edition. Belmont, CA: Wadsworth.

Triandis, Harry C. 1995. Individualism \& Collectivism. Boulder, San Francisco, Oxford: Westview Press.

Van Dijk, Teun A. 1988. News as Discourse. Hillsdale, NJ: Erlbaum.

Van Dijk, Teun A. 1998. Opinions and Ideologies in the Press. In Approaches to Media Discourse, edited by Allan Bell and Peter Garrett, 21-63. Oxford: Blackwell.

Van Dijk, Teun. 2006. Ideology and Discourse Analysis. Journal of Political Ideologies 11 (2): 115-140.

Van Dijk, Teun A. 2008. Discourse and Power. New York: Palgrave.

Varela, Juan. 2005. Ciberdiarios de Opinión. Cuadernos de Periodistas 5: 27-32.

Wahl-Jorgensen, Karin. 2004. Playground of the Pundits or Voice of the People? Comparing British and Danish Opinion Pages. Journalism Studies 5 (1): 59-70.

Wojcieszak, Magdalena, and Hernando Rojas. 2011. Correlates of Party, Ideology and Issue Based Extremity in an era of Egocentric Publics. The International Journal of Press/Politics 16 (4): 488507.

\section{About the Authors}

\section{Antonio Pineda}

Antonio Pineda is Senior lecturer at the Department of Audiovisual Communication and Advertising and Literature (University of Seville, Spain). He holds a PhD in Communications from the University of Seville, which he received in 2005 . The theoretical and empirical study of propaganda, and the relationships between the media and ideology, are two of his main current research interests.

\section{Núria Almiron}

Núria Almiron has been Senior lecturer at the Department of Communications at Universitat Pompeu Fabra since 2008. She holds a PhD in Journalism and Communication from Universitat Autònoma de Barcelona. She also holds a B.A. in Political Science (1994) and a B.A. in Communication Sciences (1992) from the same University. 